\title{
Integrating the Analytical Hierarchy Process (AHP) and the Frequency Ratio (FR) Model in Landslide Susceptibility Mapping of Shiv-khola Watershed, Darjeeling Himalaya
}

\author{
Sujit Mondal ${ }^{1, *}$ and Ramkrishna Maiti $^{2}$ \\ ${ }^{1}$ Department of Geography, Raja N. L. Khan Women's College, Paschim Medinipur, West Bengal, 721102, India \\ ${ }^{2}$ Department of Geography and Environment Management, Vidyasagar University, Paschim Medinipur, West Bengal, 721102, India
}

\begin{abstract}
To prepare a landslide susceptibility map of Shivkhola watershed, one of the landslide prone parts of Darjeeling Himalaya, remote sensing and GIS tools were used to integrate 10 landslide triggering parameters: lithology, slope angle, slope aspect, slope curvature, drainage density, upslope contributing area (UCA), lineament, settlement density, road contributing area (RCA), and land use and land cover (LULC). The Analytical Hierarchy Process (AHP) was applied to derive factor weights using MATLAB with reasonable consistency ratio (CR). The frequency ratio (FR) model was used to derive class frequency ratio or class weights that indicate the relative importance of individual classes for each factor. The weighted linear combination (WLC) method was used to determine the landslide susceptibility index value (LSIV) on a GIS platform, by incorporating both factor weights and class weights. The Shiv-khola watershed is classified into five landslide susceptibility zones. The overall classification accuracy is 99.22 and Kappa Statistics is 0.894 .
\end{abstract}

Keywords Analytical Hierarchy Process (AHP), frequency ratio (FR) model, India, landslide susceptibility, West Bengal

\section{Introduction}

The identification of the causative factors is the basis of many methods of landslide susceptibility assessment. The spatial distribution of slope instability is essential for land use planning. Landslides are the result of two interacting sets of forces: (1) natural precondition factors that govern the stability conditions of slopes; and (2) preparatory and triggering factors caused by either natural factors or human intervention. Landslide analysis is mainly done by assessing susceptibility, hazard, and risk. The remote sensing and GIS based landslide hazard zonation approach was studied by Nautiiyal (1966), Muthu and Petrou (2007), Wu and Qiao (2009), and other researchers. Rowbotham and Dudycha (1998), Donati and Turrini (2002), Lee and Choi (2003), Lee et al. (2004), Lee, Choi, and Min (2004), Lee and Pradhan (2007), Pradhan

\footnotetext{
* Corresponding author. E-mail: mandalsujit2009@gmail.com
}

and Lee (2010a, 2010b), Sarkar and Kanungo (2004), and Pandey et al. (2008) studied and applied the probabilistic model for landslide susceptibility and risk evaluation. Guzzetti et al. (1999), Pistocchi, Luzi, and Napolitano (2002) and Dai and Lee (2002) summarized many landslide hazard evaluation studies. Jibson, Edwin, and John (2000) and Zhou et al. (2002) applied the probabilistic models for landslide risk and hazard analysis. Vijith and Madhu (2008) introduced the logistic regression model for landslide hazard mapping.

The models in connection to slope stability and shallow and deep seated landslides were introduced and verified by Bhattarai and Aoyama (2001) and Bradinoni and Church (2004). The geotectonic factors of slope instability were studied in detail by Carson (1975), Windisch (1991), and Borga et al. (1998). Comprehensive lists of stability factors commonly employed in the factors mapping approach were given by Guzzetti et al. (1999) and Tiwari and Marui (2003, 2004).

The Analytical Hierarchy Process (AHP), a semiquantitative method based on decomposition, comparative judgment, and synthesis of priorities is often useful for regional susceptibility studies as suggested by Saaty (1980), Yalcin and Bulut (2007), and Yalcin (2008). The frequency ratio (FR) model has also become a popular and realistic quantitative approach in landslide susceptibility mapping. This approach is related to historical landslide events and their areal coverage. Lee and Pradhan (2007) argued that the frequency ratio model provides a correlation between historical slide locations and various influencing factors under consideration. Intarawichian and Dasananda (2011) applied the frequency ratio model to analyze slope instability and treated the model as a popular quantitative method.

This study deals with the estimation of factor weights and class frequency ratios using the AHP and FR model respectively. Integration between factor weight (FW) and class frequency ratio (FR) was performed with the help of a linear combination model. This is done to derive pixelwise landslide susceptibility index values (LSIV) and prepare a landslide susceptibility map. 
Tectono-statigraphically, the study area, Shiv-khola watershed (Figure 1) is located in the southern escarpment slope of Darjeeling Himalaya, where high-grade metamorphic rocks of the Darjeeling and Chungthang groups are thrust over lowgrade metamorphic rocks of the Daling Group along the Main Central Thrust (MCT) (Mallet 1875; Sinha-Roy 1982). The MCT and the Main Boundary Thrust (MBT) pass through the study area (Figure 2). The MCT (a major ductile shear zone) divides two major litho-tectonic units, the Higher Himalayan Crystalline Sequence (HHCS) and the Lesser Himalayan Sequence (LHS) in Darjeeling Himalaya. The HHCS comprises quartzo-feldspathic gneisses of both igneous and sedimentary origin that have been subjected to a high grade of metamorphism (Catlos et al. 2001). The LHS is dominated by garnet-biotite-mica schist and chlorite schists in the upper part and slates and phyllites in the lower part. The landslide affected areas are Paglajhora, Tindharia, Gayabari, Mahanadi, Jogmaya and Shiviter. During the rainy season water percolates through the exposed rock joints and entrains the finer particles and reduces the cohesive strength of the soil.

Rapid urbanization and expansion of tourism in Darjeeling Himalaya are putting unprecedented pressure on land and

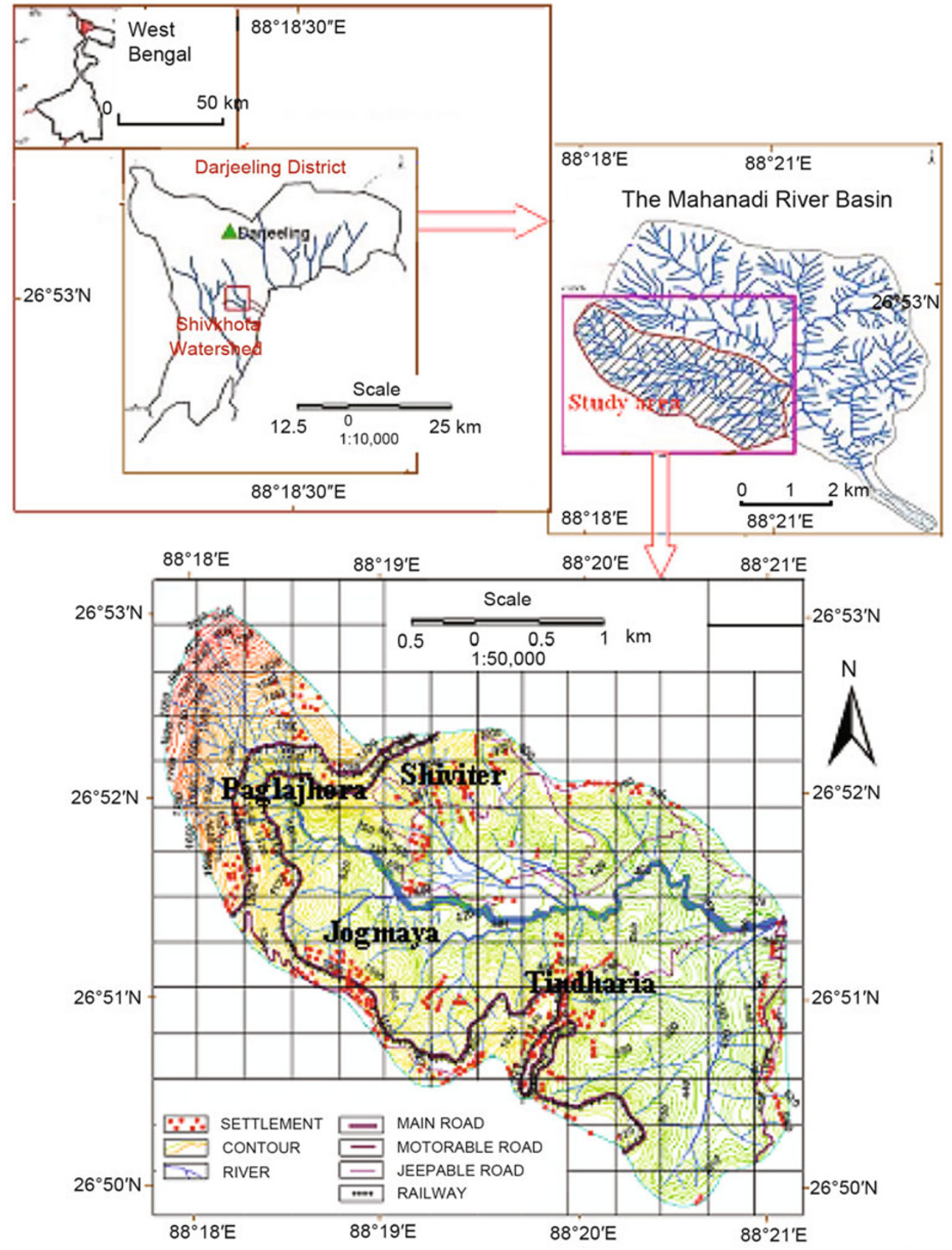

Figure 1. Location map of the Shiv-khola watershed in West Bengal, India

Source: Mondal and Maiti (2011). 


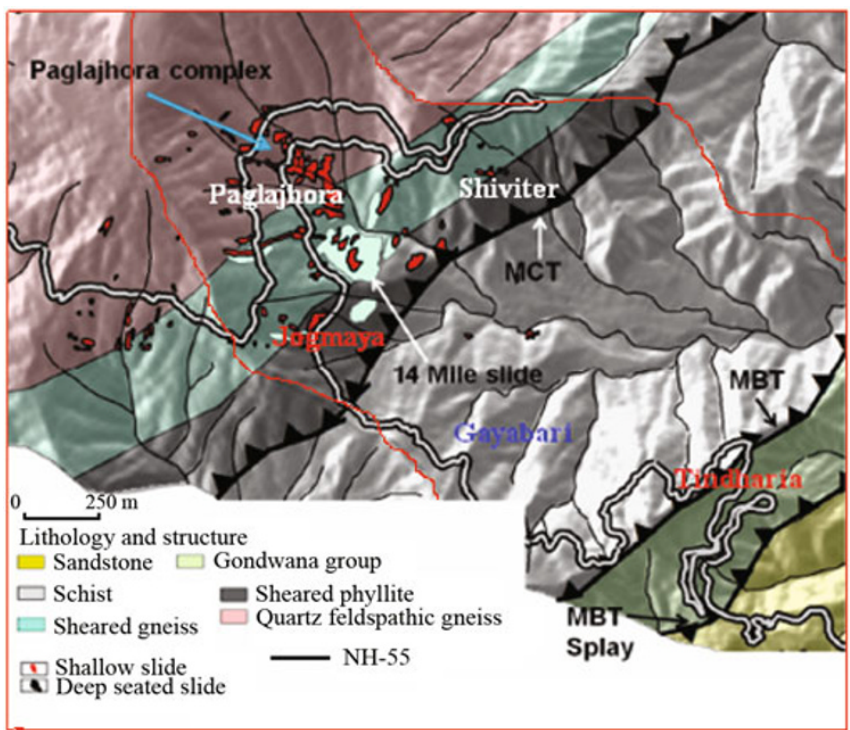

Figure 2. Tectono-stratigraphy and past landslides in the study area

Source: Geological Survey of India (East Kolkata), 2009.

soil with the gradual elimination of virgin forest land after independence. Lack of land use planning coupled with vulnerable geological structures and frequent heavy rainfall have led to the formation of a vicious cycle of soil erosion and landslides during and after the monsoon seasons, causing devastating damage to human lives and properties. Significant studies in the Darjeeling Himalaya identified the causes and consequences of major landslide occurrences (Dutta 1966). Since 1968 the Shiv-khola watershed has experienced 128 reachable landslide events, of which 76 were considered as reactivated (less than $70 \mathrm{~m}$ from old landslides) and 52 as fresh events ( $70 \mathrm{~m}$ or more from old landslides). These landslide events took place in 16 years, out of which 12 were considered major landslide years. All the landslide events occurred during the monsoon period with continuous and heavy showers. Rainfall on all the major landslide event dates was more than the critical rainfall calculated after Borga et al. (1998). Most of the landslide events occurred in the lithological unit of Darjeeling Gneiss, Daling, Damuda, and Siwalik.

In the Shiv-khola watershed, Lower Paglajhora, Tindharia, Shiviter, Gayabari, and Mahanadi are the major and prominent landslide locations where settlements, communication lines, and tea garden areas are being affected severely by the frequent occurrence of landslides. Since 1968, Paglajhora alone has had 10 landslide events, all in the above-mentioned landslide event years. The majority of these landslides was dangerous as in most of the events Hill Cart Road (NH-55) was affected and the communication line between Siliguri and Darjeeling was completely interrupted, from days to months. Paglajhora sinking zone faced massive slope failures in 1998, 2002, 2005, and 2011, which indicates that the occurrence of landslides in the region is ongoing. This poses a tremendous threat to upslope settlements and the Hill Cart Road (life line between Siliguri and Darjeeling Town). The landslide events at Tindharia also frequently cut off the Hill Cart Road and threaten the safety of tourists, upslope settlements, and tea gardens. In Shiviter, around eight acres of land were destroyed by destructive slope failure in the past 10 years. The physiographic configuration (arcuate) that provides a favorable condition for producing hydrostatic pressure, proximity to the Main Central Thrust (MCT) and the Main Boundary thrust (MBT), intensely fractured and sheared bedrock, toe cutting and headward erosion of debris covered slope by first-order tributaries, immense pressure over the fragile slope materials from manmade concrete structures, moderate to steep slope gradient, improper drainage network orientation, and accumulation of highly anisotropic materials with a great thickness and low shearing resistance have made these landslide locations in the Shiv-khola watershed most unstable in character.

\section{Data and Methods}

In this study, thematic data layers of all the landslide inducing factors were integrated to prepare a landslide susceptibility map using a linear combination model in GIS. The Analytical Hierarchy Process (AHP) was used to derive the prioritized factor rating value (PFRV) and a Frequency Ratio (FR) model was applied to obtain the prioritized class rating value (PCRV) for all the landslide triggering factors considered in the study. The integration between PFRV and PCRV was made in a linear combination model on a GIS platform to estimate the landslide susceptibility index value (LSIV) for each pixel and a suitable classification technique was incorporated to prepare the landslide susceptibility map of the Shiv-khola watershed. The data used in the study are: satellite image (IIRS P6/Sensor-LISS- III, Path-107, Row-052, date 18 March 2010); modified shuttle radar topography mission (SRTM) data with scene size 1 degree latitude and 1 degree longitude (date 5 April 2008); Google Earth image (1 September 2010); geological map (Geological Survey of India, East Kolkata); and topographic map (78B/5, Survey of India). Data layers for landslide inducing factors were generated using ERDAS Imagine 8.5, ArcView, and ArcGIS Software.

\section{Analyses}

The following section presents the methods and results of the landslide analyses in this study.

\subsection{Determination of Landslide Triggering Factors}

The landslide triggering factors were identified by interviewing the local people and an investigation of the landslide sites in the watershed through intensive fieldwork. During the 10 days fieldwork in July 2011, landslide locations were 
identified with GPS, and lithological structure, land use and land cover type around the landslide scars, slope angles, construction of manmade structures and their role in promoting landslides, drainage networks, altitude, and slope aspects were investigated to determine important landslide triggering factors. Ten landslide triggering factors including lithology, slope angle, drainage, slope aspect, slope curvature, lineament, upslope contributing area (UCA), land use and land cover (LULC), road contributing area (RCA), and settlement density were taken into account to prepare the landslide susceptibility map of the Shiv-khola watershed and their hierarchical arrangement was made on priority basis. Shiv-khola watershed is a small mountain basin where rainfall is uniformly distributed over the entire area, so rainfall intensity was not considered in the landslide susceptibility calculation (Mondal and Maiti 2011).

\subsection{Generation of Landslide Inducing Factor Maps}

First, the contour map at $20 \mathrm{~m}$ intervals was digitized from the Survey of India (SOI) topographic map $(1987,78 \mathrm{~B} / 5)$ at the scale of 1:50,000 and subsequently employed for generating the digital elevation model (DEM) using the ArcGIS Software. Then slope gradient, slope curvature, and slope aspect maps were derived from DEM with $25 \mathrm{~m} \times 25 \mathrm{~m}$ grid cell size and a supervised classification was made to derive all these parameters in raster value domain following the earlier works of Dhakal, Amada, and Aniya (2000). Surface curvature is a topographic attribute that describes the convexity/concavity of a terrain surface. Curvature depicts the slope gradient or slope direction (aspect), usually in a particular direction (Gallant and Wilson 2000). A positive curvature indicates the surface is upwardly convex at a grid cell and a negative curvature indicates the surface is upwardly concave at that grid cell. A value of zero indicates the surface is flat. The expected values of all three output raster images for a hilly area can vary from -0.5 to 0.5 ; for steep, rugged mountains the value can vary between -4 and 4 .

The lithological map of the study area was collected from the Geological Survey of India (GSI), Kolkata (Eastern Region) and necessary modifications were incorporated after intensive field investigation. The final lithological map was made with seven rock types and transformed into raster value domain in ArcGIS. Class weight value for each lithological class was assigned according to rock mass strength, described by GSI. A drainage density map (length of drainage $/ \mathrm{m}^{2}$ ) was made at the grid resolution of $23.5 \mathrm{~m} \times 23.5 \mathrm{~m}$ from the topographic map $(78 \mathrm{~B} / 5)$ and classified into 10 equal intervals.

Lineament indicates the zone of weakness, representing some linear to curvilinear features such as fracture, joint, and fault in the geological structure. There is no basic difference between these three features. All these linear to curvilinear features were identified as the same deformed surface where the propensity of slope instability is very high. To generate a lineament map (distance from lineament in meters) of the
Shiv-khola watershed, PCI-GEOMATICA was used and in the extraction process three SRTM bands were taken into account: Near Infrared (Band-I, 0.7-1.3 $\mu \mathrm{m}$ ), Red (Band-II, 0.6-0.7 $\mu \mathrm{m}$ ), and Green (Band-III, 0.5-0.6 $\mu \mathrm{m}$ ). The algorithm used to prepare the lineament map is Lineament Extraction. The study area was classified into 10 classes on the basis of distance (m) from lineaments.

Upslope contributing area (UCA) is an effective indicator of drainage concentration over space. The place with more contributing area encompasses more soil saturation and reduces soil cohesion. Specific contributing area (total contributing area divided by the contour length) is computed by distributing flow from a pixel among its entire lower elevation neighbor pixel (Borga et al. 1998) (Eq. 1). An upslope contributing area map was prepared based on the calculated contributing area value for each $0.25 \mathrm{~km}^{2}$ grid and the map was divided into 6 equal classes.

$$
F_{i}=\frac{S_{i} L_{i}}{\sum_{i} S_{i} L_{i}}
$$

where, the summation $\left(\Sigma_{i}\right)$ is for the entire lower neighbors, $S$ is the directional slope, and $L$ is the effective contour length that acts as the weighting factor. The value of $L$ used here is $10 \mathrm{~m}$ (the pixel size) for the cardinal neighbors and $14.14 \mathrm{~m}$ (the pixel diagonal) for diagonal neighbors.

The road contributing area (RCA) map was made by multiplying road contributing length (RCL) with road contributing width (RCW) and was classified into eight equal classes from the concerned topographic map and converted into raster value domain in ArcGIS. The settlement density map was prepared by applying a $3 \times 3$ kernel in ArcGIS and the basin was classified into seven equal density classes. The land use and land cover (LULC) map of the watershed was prepared with the help of the LISS-III satellite image (2010) and the Google Earth image in consultation with the SOI topographic map $(78 \mathrm{~B} / 5)$. After verifying the ground truth with GPS a land use and land cover map was developed in GIS. The Shiv-khola watershed was classified into 10 individual land use types (bare surface, agricultural land, jungle, roads, settlement, tea garden, open forest, degraded forest, mixed forest, and dense forest).

\subsection{Landslide Inventory Map}

A landslide distribution or inventory map (Figure 3) was created to determine landslide affected areas (\%) and frequency of landslides for each class of the landslide inducing factors. Mondal and Maiti (2011) identified major and minor landslide locations during field investigation and mapped them by evaluating the SOI topographic map (78B/5), satellite image (IRS LISS- III, 2000), SRTM data (2008), and Google Earth image (2000). Several field investigations were conducted to identify the landslide locations as well as to cross-check the prepared landslide map. Then, the map was digitized and converted into raster value domain in ArcGIS. All the landslide 


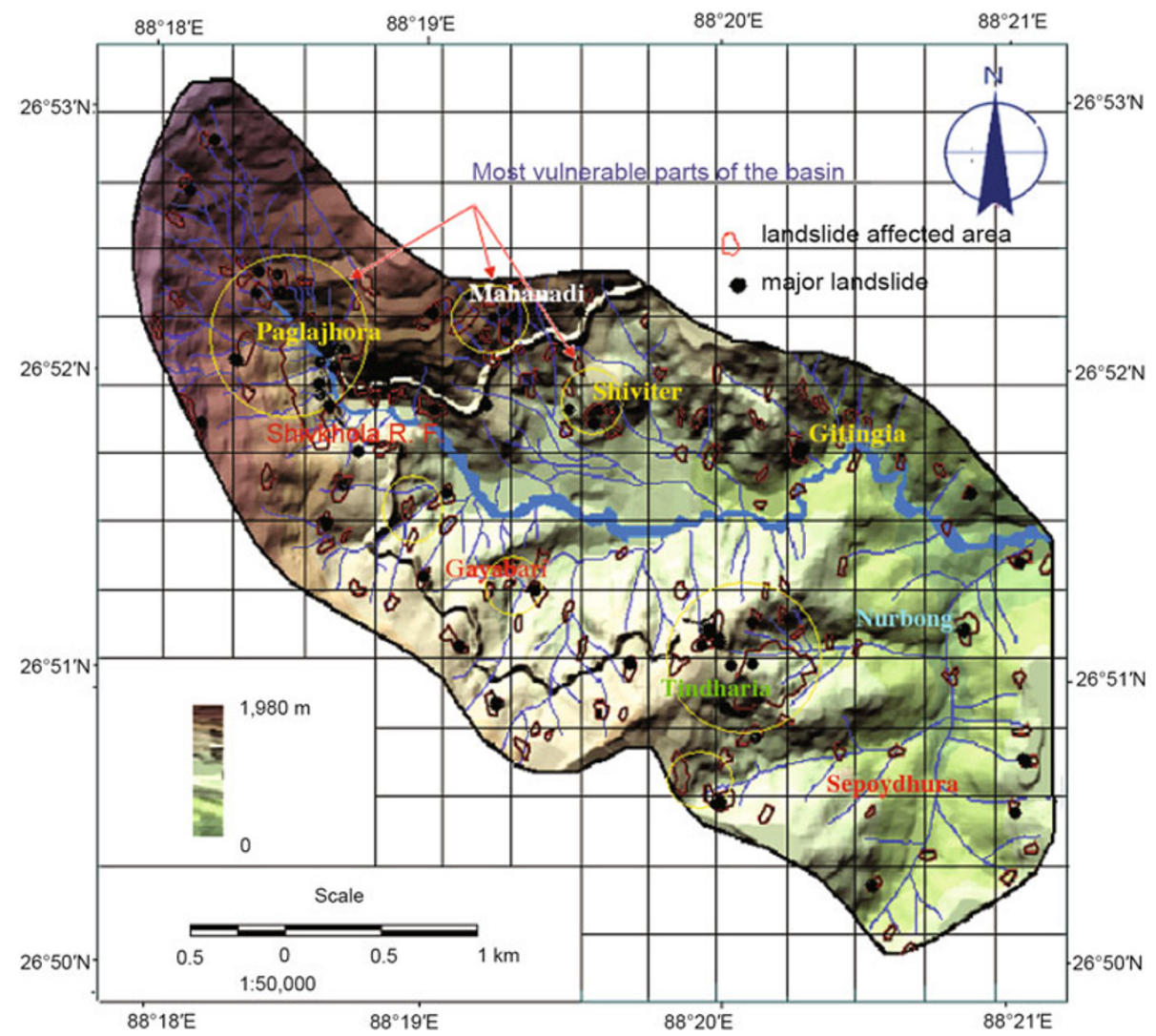

Figure 3. Landslide inventory map of the Shiv-khola watershed in West Bengal, India Source: Mondal and Maiti (2011).

triggering factor maps were incorporated with this landslide inventory map to understand the degree of importance of each factor in landsliding.

\subsection{The Analytical Hierarchy Process (AHP) and the Prioritized Factor Rating Value (PFRV)}

AHP is a decision-making and semi-quantitative value judgment approach that serves the objectives of the decision makers. This process is employed in this study to support the decision on the instability rank of the factors by estimating the prioritized factor rating value (PFRV). In the AHP, different factor preferences and their conversion into numerical values were accomplished with the help of comparative oral judgment based on interviewing the local people inhabiting in the landslide prone area and synthesis of priorities (Table 1). A pairwise comparison matrix for the study area was constructed on the basis of the preference of a factor as compared with the other factor and arithmetic mean method was applied to arrange landslide triggering factors hierarchically and to determine the prioritized factor rating value/eigenvector (PFRV) with reasonable consistency ratio (CR), based on Saaty (1977, 1980) and Saaty and Vargas (2000), using MATLAB (Table 2). To develop the pairwise comparison matrix, each factor was rated against every other factor by assigning a relative dominant value ranging between 1 and 9 on the basis of the relative importance of the factors in relation to landslide frequency. The value also varies between the reciprocals $1 / 2$ and 1/9 for inverse comparison (Table 1).

Another appealing feature of the AHP is the ability to evaluate pairwise rating inconsistency. The eigenvalues enable the quantification of a consistency measure that is an indicator of the inconsistencies or intransivities in a set of pairwise ratings. Saaty and Vargas (2000) stated that for a consistent reciprocal matrix, the largest eigenvalue $\lambda_{\max }$ is equal to the number of comparisons $n$. An index of consistency, known as the CR (Consistency Ratio), is used to indicate the probability that the matrix judgments were randomly generated (Saaty 1977).

$$
\mathrm{CR}=\mathrm{CI} / \mathrm{RI}
$$

where RI is the average of the resulting consistency index depending on the order of the matrix given by Saaty and CI is the consistency index that is expressed in Eq. 3. If the value of $\mathrm{CR}$ is smaller or equal to 10 percent, the inconsistency is acceptable, but if the $\mathrm{CR}$ is greater than 10 percent, the subjective judgment needs to be revised (Saaty 1977).

$$
\mathrm{CI}=\lambda_{\max }-n / n-1
$$

Saaty and Vargas (2000) randomly produced reciprocal matrices using scales $1 / 9,1 / 8,1 / 7 \cdots 1 \cdots 8,9$ to evaluate a so-called random consistency index (RI). The average RI of 500 matrices is given in Table 3 . 
Table 1. Scale of preference between two parameters

\begin{tabular}{lll}
\hline Scale & Degree of Preference & Explanation \\
\hline 1 & Equally & Two activities contribute equally to the objective \\
3 & Moderately & Experience and judgment slightly to moderately favor one activity over another \\
5 & Strongly & Experience and judgment strongly or essentially favor one activity over another \\
7 & Very Strongly & An activity is strongly favored over another and its dominance is showed in practice \\
9 & Extremely & The evidence of favoring one activity over another is of the highest degree possible of an affirmation \\
$2,4,6$, and 8 & Intermediate values & Used to represent compromises between the references in weight $1,3,5,7$, and 9 \\
Reciprocals & Opposites & Used for inverse comparison \\
\hline
\end{tabular}

Source: Saaty and Vargas (2000).

Table 2. Landslide triggering factors and prioritized factor rating values (weights) in the Shiv-khola watershed, West Bengal, India

\begin{tabular}{|c|c|c|c|c|c|c|c|c|c|c|c|}
\hline Factors & 1 & 2 & 3 & 4 & 5 & 6 & 7 & 8 & 9 & 10 & Prioritized Rating (PFRV) \\
\hline (1) Slope & 1 & 2 & 3 & 4 & 5 & 6 & 7 & 8 & 9 & 9 & 0.2944 \\
\hline (2) Lithology & $1 / 2$ & 1 & 2 & 3 & 4 & 5 & 6 & 7 & 8 & 9 & 0.2150 \\
\hline (3) Drainage & $1 / 3$ & $1 / 2$ & 1 & 2 & 3 & 4 & 5 & 6 & 7 & 8 & 0.1537 \\
\hline (4) Lineament & $1 / 4$ & $1 / 3$ & $1 / 2$ & 1 & 2 & 3 & 4 & 5 & 6 & 7 & 0.1087 \\
\hline (5) Curvature & $1 / 5$ & $1 / 4$ & $1 / 3$ & $1 / 2$ & 1 & 2 & 3 & 4 & 5 & 6 & 0.0764 \\
\hline (6) UCA & $1 / 6$ & $1 / 5$ & $1 / 4$ & $1 / 3$ & $1 / 2$ & 1 & 2 & 3 & 4 & 5 & 0.0535 \\
\hline (7) $\mathrm{RCA}$ & $1 / 7$ & $1 / 6$ & $1 / 5$ & $1 / 4$ & $1 / 3$ & $1 / 2$ & 1 & 2 & 3 & 4 & 0.0375 \\
\hline (8) LULC & $1 / 8$ & $1 / 7$ & $1 / 6$ & $1 / 5$ & $1 / 4$ & $1 / 3$ & $1 / 2$ & 1 & 2 & 3 & 0.0266 \\
\hline (9) Settlement Density & $1 / 9$ & $1 / 8$ & $1 / 7$ & $1 / 6$ & $1 / 5$ & $1 / 4$ & $1 / 3$ & $1 / 2$ & 1 & 2 & 0.0193 \\
\hline (10) Slope Aspect & $1 / 9$ & $1 / 9$ & $1 / 8$ & $1 / 7$ & $1 / 6$ & $1 / 5$ & $1 / 4$ & $1 / 3$ & $1 / 2$ & 1 & 0.0149 \\
\hline
\end{tabular}

$\mathrm{CI}($ consistency index $)=0.0615 ; \mathrm{RI}($ random consistency index $)=1.49$; and $\mathrm{CR}=0.0413$ (consistent)

$\mathrm{RCA}=$ Road contributing area; $\mathrm{UCA}=$ Upslope contributing area; $\mathrm{LULC}=$ land use and land cover

Table 3. Random consistency index (RI)

\begin{tabular}{llllllllllllllll}
\hline$N$ & 1 & 2 & 3 & 4 & 5 & 6 & 7 & 8 & 9 & 10 & 11 & 12 & 13 & 14 & 15 \\
\hline RI & 0 & 0 & 0.58 & 0.90 & 1.12 & 1.24 & 1.32 & 1.41 & 1.45 & 1.49 & 1.51 & 1.53 & 1.56 & 1.57 & 1.59 \\
\hline
\end{tabular}

Source: Saaty (1977).

\subsection{Frequency Ratio (FR) Model and Prioritized Class Rating Value (PCRV)}

The frequency ratio (FR) model is a well accepted and popular quantitative approach for the preparation of landslide susceptibility maps. Lee and Talib (2005), Lee and Pradhan (2007), Jadda (2009), Avinash and Ashamanjari (2010), and Intarawichian and Dasananda (2011) successfully applied the FR model to generate landslide susceptibility zoning maps. To obtain the frequency ratio (FR) for each class of all the data layers a combination has been established between the landslide inventory map and factor maps using the following equation.

$$
\mathrm{FR}=\frac{N_{\mathrm{pix}\left(S_{i}\right)} / N_{\mathrm{pix}\left(N_{i}\right)}}{\sum_{i} N_{\operatorname{pix}\left(S_{i}\right)} / \sum_{i} N_{\operatorname{pix}\left(N_{i}\right)}}
$$

where $N_{\text {pix }\left(S_{i}\right)}$ is the number of pixels containing slide in class $i, N_{\operatorname{pix}\left(N_{i}\right)}$ is the total number of pixels having class $i$ in the watershed, $\sum_{i} N_{\text {pix }\left(S_{i}\right)}$ is the total number of pixels containing landslide, $\sum N_{\text {pix }\left(N_{i}\right)}$ is the total number of pixels in the watershed.

The derived frequency ratio (FR) value of more than 1 indicates strong and positive relationship between landslide occurrences and the concerned class of the data layer and high landslide susceptibility, whereas a FR value of less than 1 depicts negative relationship and low landslide susceptibility. In this study, the FR value for each class is accepted as prioritized class rating value or prioritized class weight.

\subsection{Linear Combination Model and Landslide Susceptibility Classification}

Avinash and Ashamanjari (2010) and Intarawichian and Dasananda (2011) used a landslide susceptibility index value (LSIV), which is the summation of class- and factor-weighted values. FR values for each class (PCRV or prioritized class 
weight) as well as prioritized factor rating values (PFRV) for each factor map were taken into account in calculating the landslide susceptibility index value (LSIV) with the following linear combination model:

$$
\operatorname{LSIV}=\sum_{i}^{n}{ }_{i=1}\left(W_{i} \times \mathrm{FR}_{i}\right) \times \mathrm{FV}
$$

where, $n$ is the total number of factors included in the study ( $n=10), W_{i}$ is factor weight (PFRV), FV is factor value, and $\mathrm{FR}_{i}$ is class frequency ratio or prioritized class weight.

In this study, the LSIV varied from 4.81 to 16.00 . The higher the value of LSIV, the greater was the propensity of landslide occurrence and vice versa. The frequency distribution of landslide susceptibility index values shows that the LSIV based frequency curve has many oscillations. To produce a better classification of the watershed into landslide susceptibility zones, moving average with averaging window lengths of $3,5,7$, and 9 was considered for smoothing the frequency distribution curve (Figure 4). After analyzing the four new curves, the watershed was classified into five landslide susceptibility zones: Very Low, Low, Moderate, High, and Very High, with class boundaries at the significant changes of gradient of these curves. The abrupt change points on frequency curves (landslide threshold boundaries) were 7.05, 9.29, 11.5, and 13.8. A $3 \times 3$ "majority filter" was applied to the map as a post-classification filter to reduce the high frequency variation.

To verify the landslide susceptibility map, landslide density under each susceptibility class was computed. The landslide inventory map was crossed with the calculated landslide susceptibility map to derive landslide affected pixels for each susceptibility class (zone). Research by Sarkar and Kanungo (2004) indicates that the higher the landslide density, the greater is the probability of and the area affected by landslides in a landslide susceptibility class.

\subsection{Accuracy Assessment of the Landslide Susceptibility Map with Field Data}

Accuracy was assessed by comparing the classification with geographical data that are assumed to be true using Erdas Imagine (8.5). Ground truth verification data were obtained with the help of GPS from 50 existing landslide locations. Simultaneously, 50 randomly selected reference pixels from the classified image corresponding to the 50 landslide locations (GPS record) were used for evaluating the validity of the landslide susceptibility map (Congalton 1991).

\section{Landslide Susceptibility of the Shiv-khola Watershed}

An effective management to prevent slope failure deals with the triggering factors and their roles in landsliding. The following section presents the relationship between various landslide inducing factors and landslide susceptibility, as well as landslide susceptibility characterization in the study area.

\subsection{The Relationship between Landslide Susceptibility and Triggering Factors}

Landslide susceptibility of the Shiv-khola watershed was affected by the interaction between landslide triggering factors and existing landslides. Class frequency ratio indicates the relative importance of individual classes for each factor and provides important information for analyzing the role of these factors in inducing landslides. The class frequency ratios (prioritized class weights) of the 10 landslide triggering factors are presented in Table 4. (1) Slope gradient of the watershed varies from very gentle (around $10^{\circ}$ ) in the

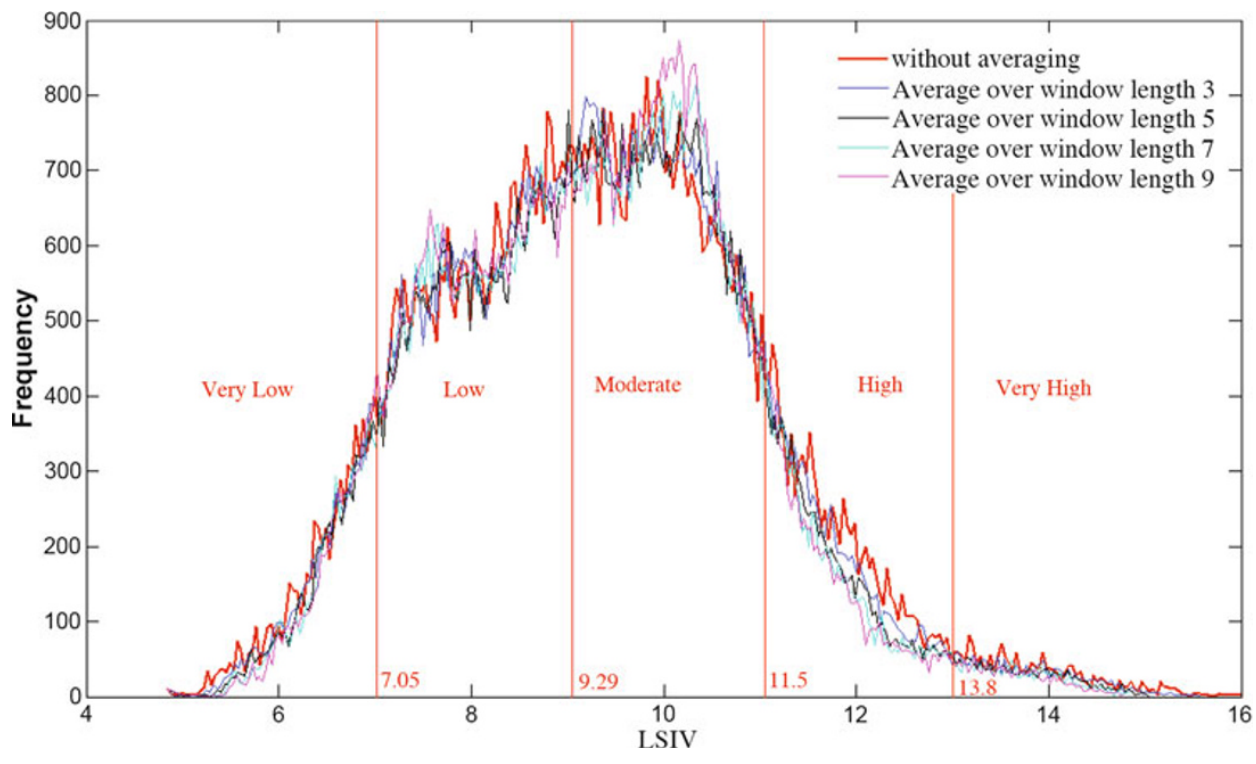

Figure 4. Frequency distribution of landslide susceptibility index value of the Shiv-khola watershed in West Bengal, India 
Table 4. Class frequency ratio (prioritized class rating value)

\begin{tabular}{|c|c|c|c|c|c|}
\hline \multicolumn{6}{|c|}{ Slope Gradient (degree)-1 } \\
\hline Classes & Number of Pixels $\left[N_{\text {pix }\left(N_{i}\right)}\right]$ & $\%$ of $N_{\text {pix }\left(N_{i}\right)}$ & Landslide Pixels $\left[N_{\text {pix }\left(S_{i}\right)}\right]$ & $\%$ of $N_{\text {pix }\left(S_{i}\right)}$ & FR/PCRV \\
\hline $0-7.17$ & 3,353 & 10.12 & 190 & 5.63 & 0.53 \\
\hline $7.17-14.34$ & 3,238 & 9.77 & 202 & 5.99 & 0.61 \\
\hline $14.34-19.92$ & 3,587 & 10.83 & 211 & 6.26 & 0.58 \\
\hline $19.92-24.97$ & 2,445 & 7.38 & 201 & 5.96 & 0.81 \\
\hline $24.97-29.75$ & 3,555 & 10.73 & 311 & 9.22 & 0.86 \\
\hline $29.75-34.53$ & 2,776 & 8.38 & 329 & 9.75 & 1.16 \\
\hline $34.53-39.57$ & 3,854 & 11.63 & 413 & 12.24 & 1.05 \\
\hline $39.57-45.95$ & 3,276 & 9.89 & 417 & 12.36 & 1.25 \\
\hline $45.95-54.71$ & 3,557 & 10.74 & 523 & 15.51 & 1.44 \\
\hline $54.71-67.73$ & 3,490 & 10.53 & 626 & 18.56 & 1.76 \\
\hline \multicolumn{6}{|c|}{ Slope Aspect (direction of slope)-2 } \\
\hline Flat & 784 & 2.37 & 24 & 0.711 & 0.30 \\
\hline North & 3,879 & 11.71 & 665 & 19.72 & 1.68 \\
\hline Northeast & 3,797 & 11.46 & 443 & 13.13 & 1.15 \\
\hline East & 4,346 & 13.12 & 675 & 20.01 & 1.53 \\
\hline Southeast & 6,290 & 18.99 & 789 & 23.39 & 1.23 \\
\hline South & 4,556 & 13.75 & 597 & 17.70 & 1.29 \\
\hline Southwest & 3,332 & 10.06 & 35 & 0.74 & 0.07 \\
\hline West & 2,870 & 8.66 & 69 & 2.05 & 0.24 \\
\hline Northwest & 3,277 & 9.89 & 76 & 2.25 & 0.23 \\
\hline \multicolumn{6}{|c|}{ Slope Curvature (positive, negative, and zero)-3 } \\
\hline$-25.87--11.41$ & 995 & 3.00 & 221 & 6.55 & 2.18 \\
\hline$-11.41--5.73$ & 785 & 2.37 & 210 & 6.23 & 2.63 \\
\hline$-5.73--2.33$ & 2,111 & 6.37 & 486 & 14.40 & 2.26 \\
\hline$-2.33--0.63$ & 2,431 & 7.34 & 374 & 11.09 & 1.51 \\
\hline$-0.63-0.50$ & 10,045 & 30.32 & 388 & 11.50 & 0.38 \\
\hline $0.50-2.49$ & 6,302 & 19.02 & 268 & 7.95 & 0.42 \\
\hline $2.49-7.31$ & 5,438 & 16.41 & 464 & 13.76 & 0.84 \\
\hline $7.31-14.69$ & 3,343 & 10.09 & 475 & 14.08 & 1.40 \\
\hline $14.69-24.33$ & 895 & 2.70 & 222 & 6.58 & 2.44 \\
\hline $24.33-46.45$ & 786 & 2.37 & 265 & 7.86 & 3.32 \\
\hline \multicolumn{6}{|c|}{ Lineaments (distance from lineament, m)-4 } \\
\hline $0-57.42$ & 3,381 & 10.20 & 624 & 18.50 & 1.81 \\
\hline $57.42-126.32$ & 3,786 & 11.43 & 668 & 19.80 & 1.73 \\
\hline $126.32-229.68$ & 3,695 & 11.15 & 451 & 13.37 & 1.20 \\
\hline $229.68-356.00$ & 3,252 & 9.82 & 522 & 15.48 & 1.58 \\
\hline $356.00-528.26$ & 4,799 & 14.48 & 444 & 13.16 & 0.91 \\
\hline $528.26-723.45$ & 4,141 & 12.50 & 286 & 8.48 & 0.68 \\
\hline $723.45-964.65$ & 3,887 & 11.73 & 221 & 6.55 & 0.56 \\
\hline $964.65-1251.75$ & 3,921 & 11.83 & 120 & 3.56 & 0.30 \\
\hline $1251.75-1642.20$ & 1,419 & 4.29 & 37 & 1.10 & 0.26 \\
\hline $1642.20-2925.40$ & 850 & 2.57 & 0 & 0 & 0 \\
\hline \multicolumn{6}{|c|}{ Drainage Density (length of drainage, $\left.\mathrm{km} / \mathrm{km}^{2}\right)-5$} \\
\hline $0-1.90$ & 5,560 & 16.78 & 90 & 2.67 & 0.16 \\
\hline $1.90-3.80$ & 5,453 & 16.46 & 109 & 3.23 & 0.20 \\
\hline $3.80-5.71$ & 3,289 & 9.93 & 158 & 4.68 & 0.47 \\
\hline $5.71-7.61$ & 5,049 & 15.24 & 137 & 4.06 & 0.27 \\
\hline $7.61-9.51$ & 3,477 & 10.49 & 159 & 4.71 & 0.45 \\
\hline $9.51-11.41$ & 2,728 & 8.23 & 455 & 13.49 & 1.64 \\
\hline $11.41-13.31$ & 1,875 & 5.66 & 534 & 15.83 & 2.80 \\
\hline $13.31-15.21$ & 2,191 & 6.61 & 532 & 15.77 & 2.39 \\
\hline $15.21-17.12$ & 1,942 & 5.86 & 687 & 20.37 & 3.48 \\
\hline $17.12-19.02$ & 1,567 & 4.73 & 562 & 16.66 & 3.52 \\
\hline
\end{tabular}


Table 4. Continued

\begin{tabular}{|c|c|c|c|c|c|}
\hline \multicolumn{6}{|c|}{ Slope Gradient (degree)-1 } \\
\hline Classes & Number of Pixels $\left[N_{\text {pix }\left(N_{i}\right)}\right]$ & $\%$ of $N_{\text {pix }\left(N_{i}\right)}$ & Landslide Pixels $\left[N_{\text {pix }\left(S_{i}\right)}\right]$ & $\%$ of $N_{\text {pix }\left(S_{i}\right)}$ & FR/PCRV \\
\hline \multicolumn{6}{|c|}{ Geology (lithological composition)-6 } \\
\hline Darjeeling gneiss & 6,695 & 20.21 & 692 & 20.52 & 1.02 \\
\hline Chungtung formation & 4,203 & 12.69 & 525 & 15.56 & 1.23 \\
\hline Lingtse granite & 3,150 & 9.51 & 475 & 14.08 & 1.48 \\
\hline Gorubathan formation & 2,945 & 8.89 & 448 & 13.28 & 1.49 \\
\hline Reyang formation & 5,925 & 17.89 & 621 & 18.41 & 1.03 \\
\hline $\begin{array}{l}\text { Damuda formation } \\
\text { (Gondwana) }\end{array}$ & 3,203 & 9.67 & 490 & 14.53 & 1.50 \\
\hline Siwalik groups & 7,010 & 21.56 & 122 & 3.62 & 0.17 \\
\hline \multicolumn{6}{|c|}{ Land Use and Land Cover (LULC)-7 } \\
\hline Tea & 2,310 & 6.97 & 290 & 8.60 & 1.23 \\
\hline Jungle & 2,657 & 8.02 & 312 & 9.25 & 1.15 \\
\hline Open forest & 531 & 1.60 & 19 & 0.56 & 0.35 \\
\hline Degraded forest & 1,522 & 4.59 & 112 & 3.32 & 0.72 \\
\hline Dense forest & 2,114 & 6.38 & 194 & 5.75 & 0.90 \\
\hline Bare surface & 4,758 & 14.36 & 379 & 11.24 & 0.78 \\
\hline Road & 1,074 & 3.24 & 216 & 6.40 & 1.98 \\
\hline Settlement & 3,037 & 9.17 & 352 & 10.44 & 1.14 \\
\hline Agricultural land & 6,880 & 20.77 & 566 & 16.78 & 0.81 \\
\hline Mixed forest & 9,281 & 28.01 & 933 & 27.66 & 0.99 \\
\hline \multicolumn{6}{|c|}{ Upslope Contributing Area $\left(\mathrm{UCA}, \mathrm{km}^{2}\right)-8$} \\
\hline$<5.00$ & 11,421 & 34.47 & 1089 & 32.29 & 0.94 \\
\hline $5.00-10.00$ & 7,520 & 22.70 & 923 & 27.36 & 1.21 \\
\hline $10.00-15.00$ & 6,611 & 19.95 & 993 & 29.44 & 1.48 \\
\hline $15.00-20.00$ & 5,215 & 15.74 & 253 & 7.50 & 0.48 \\
\hline$>20.00$ & 2,364 & 7.14 & 106 & 3.14 & 0.44 \\
\hline \multicolumn{6}{|c|}{ Road Contributing Area (RCA, km²)-9 } \\
\hline$<0.002$ & 5,720 & 17.26 & 0 & 0 & 0 \\
\hline $0.002-0.004$ & 5,307 & 16.02 & 79 & 2.34 & 0.15 \\
\hline $0.004-0.006$ & 4,220 & 12.74 & 440 & 13.04 & 1.02 \\
\hline $0.006-0.008$ & 4,370 & 13.19 & 461 & 13.67 & 1.04 \\
\hline $0.008-0.010$ & 4,003 & 12.08 & 527 & 15.62 & 1.29 \\
\hline $0.010-0.012$ & 3,522 & 10.63 & 572 & 16.96 & 1.60 \\
\hline $0.012-0.014$ & 2,957 & 8.93 & 608 & 18.03 & 2.02 \\
\hline$>0.014$ & 2,532 & 7.64 & 686 & 30.34 & 3.97 \\
\hline \multicolumn{6}{|c|}{ Settlement Density (No. of settlements/km²)-10 } \\
\hline Very low & 6,445 & 19.45 & 235 & 6.97 & 0.36 \\
\hline Low & 5,780 & 17.45 & 329 & 9.75 & 0.56 \\
\hline Moderately low & 4,858 & 14.66 & 374 & 11.09 & 0.76 \\
\hline Moderate & 4,397 & 13.27 & 499 & 14.79 & 1.11 \\
\hline Moderately high & 4,265 & 12.87 & 591 & 17.52 & 1.36 \\
\hline High & 3,774 & 11.39 & 658 & 19.50 & 1.71 \\
\hline Very high & 3,612 & 10.90 & 687 & 20.37 & 1.87 \\
\hline
\end{tabular}

mid-central and mid-lower parts to high (more than $60^{\circ}$ ) towards the margin and water divide. Most of the landslides occurred in areas with higher than $35^{\circ}$ slope gradient, whose FR (prioritized class weight) values range between 1.05 and 1.76. (2) South, southeast, north, east, and northeasterly facing slopes registered highest FR values of 1.29, 1.23, 1.68, 1.53 , and 1.15 respectively. All these slope facets were associated with moderate to high landslide susceptibility and a large number of landslide occurrences. (3) The derived FR values revealed that high to very high landslide susceptibility zones are characterized by high positive and negative curvature. Lower Paglajhora, Gayabari (Lower), Shiviter (Lower), and Tindharia Tea Estate were characterized by upwardly concave or negative curvature and highest FR values ranging from 1.51 to 2.63 . The marginal part of the watershed, mainly Upper Paglajhora, 14 Miles Bustee (upslope), Gayabari 
(Upper), and Tindharia (Upper), registered high positive curvature with maximum landslide frequency ratio. (4) Lithologically, darjeeling gneiss, gorubathan, lingste granite, and reyang formations show the highest number of landslide occurrences. Probability of landslide occurrence was very high for the lithological composition of gneiss, mica-schist, and granulite. FR values of lingtse granite, Gorubathan formation, and Chungtung formation were 1.48, 1.49, and 1.23 respectively. All these lithological groups were accompanied with a large number of landslide activities and greater chances of landslip in the future. (5) Drainage density was very high at Lower Paglajhora, Gayabari, and Shiviter Tea Estate, which were characterized by high landslide susceptibility and high FR values $(>2.5)$. The value of drainage density increases from the marginal part to the central part. The area with more that $11 \mathrm{~km}$ of drainage per $\mathrm{km}^{2}$ has the highest FR (2.39-3.48) and greater probability of landslide occurrence. (6) The study on lineament showed that most of the major landslide locations are very close to the lineaments. (7) The values of upslope contributing area (UCA) increase from the water divide and the maximum of $20.98 \mathrm{~km}^{2}$ is registered at the lowermost portion of the watershed. Places with an upslope contributing area of less than $5 \mathrm{~km}^{2}$ experience less saturation excess run-off and lower intensity of landslides. Larger contributing areas are registered along the main river. This study found that the places with an UCA of 5.00$10.00 \mathrm{~km}^{2}$ and $10.00-15.00 \mathrm{~km}^{2}$ have a high FR value of 1.21 and 1.48 , which indicates that these places are very prone to landslide hazards. (8) In the Shiv-khola watershed, tea garden, jungle, road, and settlement were characterized by high FR of $1.23,1.15,1.98$, and 1.14. The analysis shows that tea garden areas, roads, and settlements were dominated by high intensity of landslides and could be treated as maximum probable areas of landslide occurrences. (9) Road contributing area (RCA) is high in Tindharia, Paglajahora, Mahanadi, and Shiviter where the landslide frequency ratio is also very high. At all these places the RCA ranges from $0.008 \mathrm{~km}^{2}$ to $0.014 \mathrm{~km}^{2}$ and the prioritized class weight value ranges between 1.04 and 3.97. In the study area, construction of roads and slope modification caused by human intervention are very much responsible for landsliding. (10) The moderate to high density of human settlements at Tindharia, Gayabari, Shiviter, Mahanadi, and Lower Paglajhora are correlated with a high FR as well as greater probability of landslip.

\subsection{Landslide Susceptibility}

In the Shiv-khola watershed, Lower Paglajhora, Shiviter, and Tindharia were very highly susceptible to landslides; Upper Paglajhora, Gayabari, 14 Miles Bustee, and Nurbong Tea Estate were characterized by high landslide susceptibility; Mahanadi and Giddapahar were of moderate landslide potentiality; and the marginal waxing slope of the water divide and the lower-central waning slope areas have low landslide susceptibility (Figure 5).

This study revealed that around 50 percent area of the Shiv-khola watershed is in the moderate to very high landslide susceptibility zones with 73 percent of the landslide occurrences. Landslide density in each susceptibility class was derived to evaluate the intensity of landslide activities (Table 5). The landslide density value ranges from 0.03 to 0.25 . The calculated density values of 0.25 and 0.15 for very high and high landslide susceptibility zones indicate the higher intensity of landslide activities compared to other landslide susceptibility zones. Landslide density and susceptibility class reveal that the areas with high and very high landslide susceptibility would be prone to fresh landslides and this indicates the validity of the present landslide susceptibility mapping approach.

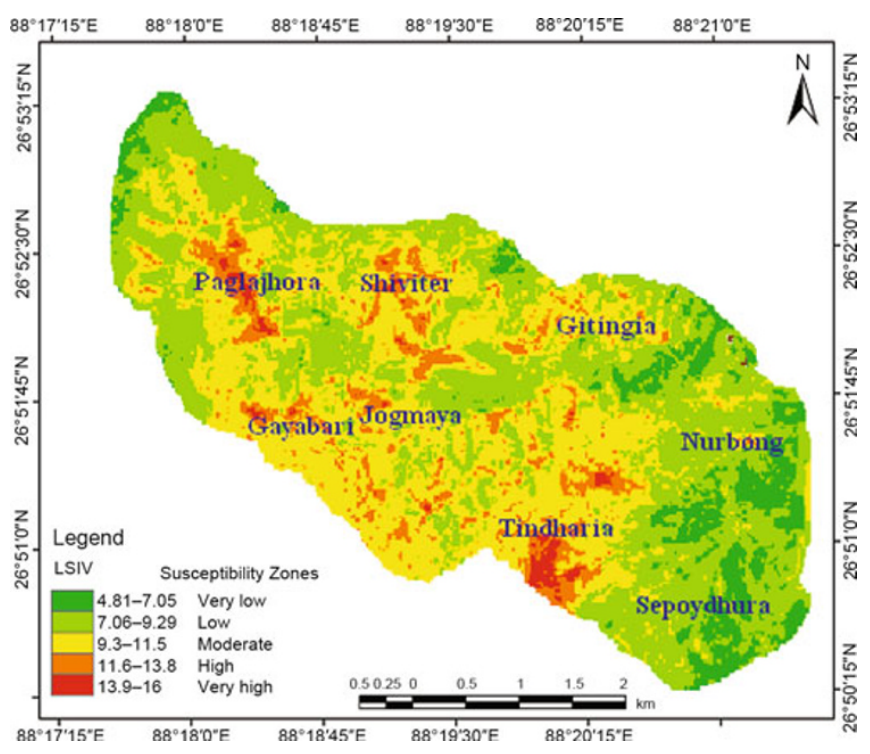

Figure 5. Landslide susceptibility map of Shiv-khola watershed in West Bengal, India

Table 5. Relationship between landslide susceptibility, and landslide density

\begin{tabular}{lcccc}
\hline Landslide Susceptibility & $\begin{array}{c}\text { Number of Pixels } \\
\mathbf{( 2 5} \mathbf{~ m \times 2 5 ~} \mathbf{~})[\mathbf{a}]\end{array}$ & \% of Pixels in Watershed & $\begin{array}{c}\text { Landslide Pixels } \\
\mathbf{( 2 5} \mathbf{~ m \times 2 5 ~} \mathbf{~ m})[\mathbf{b}]\end{array}$ & Landslide Density (b/a) \\
\hline Very low & 7,707 & 9.03 & 245 & 0.0318 \\
Low & 35,386 & 41.46 & 1247 & 0.0352 \\
Moderate & 34,364 & 40.26 & 2676 & 0.0779 \\
High & 6,932 & 8.12 & 1074 & 0.1549 \\
Very high & 964 & 1.30 & 242 & 0.2510 \\
\hline
\end{tabular}




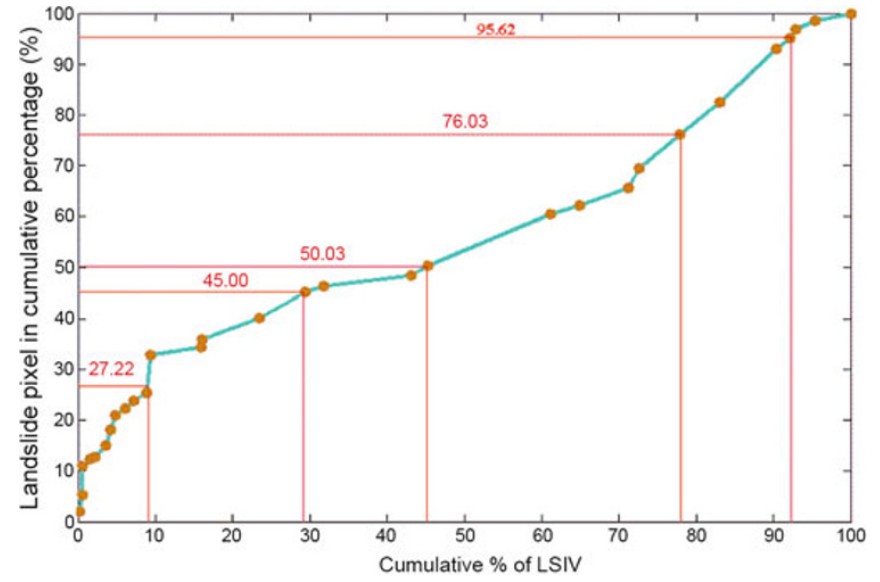

Figure 6. Relationship between landslide affected pixels and landslide susceptibility

Figure 6 shows the relationship between landslide susceptibility and landslide affected pixels: 27.22, 45.00, 50.03, 76.03 , and 95.62 percent landslide affected areas are distributed in $8.75,28.66,45,78$, and 92 percent landslide susceptible areas. Around 35 percent landslide affected pixels are distributed in 27 percent of high to very high landslide susceptibility zones, that is, areas with higher probability of landslide activities. But 73 percent landslide susceptible areas contained 65 percent landslide affected pixels.

A comparison between the ground truth data and randomly selected data from the classified image was made on a GIS platform and the result shows that the overall classification accuracy is 92.22 percent, and overall Kappa statistics is 0.894 . The class-wise accuracy result is shown in Table 6, which indicates acceptable results.

\section{Conclusion}

This study developed and applied two quantitative analyses that helped to identify landslide susceptible zones in the Shiv-khola watershed. The proposed methodology incorporated all the landslide triggering factors existing in the area. Very fragile and fragmented lithological composition allows easy percolation of rainwater that generates adequate pore water pressure for promoting downward movement of slope materials in high landslide susceptible sections of the Shivkhola watershed. The existence of moderate- to high-intensity risk elements and human intervention associated with all favorable geomorphic and geohydrologic landslide triggering factors have made Lower Paglajhora, Tindharia, and Shiviter high to very high landslide hazard risk zones in the Shivkhola watershed. Slope steepening caused by road-cut benches and toe-erosion, plying of heavy loaded vehicles and their enormous pressure on fragile slope materials, depletion of forest cover at a rapid pace, continuous and regular orographic rainfall in the rainy season, easy percolation of water through fragmented rock-soil composition and increased pore water pressure have caused destructive slope failure, damaged human structures, disrupted normal life by cutting off the communication lines at these three locations, and made these areas the most significant landslide prone sections of Darjeeling Himalaya.

The derived prioritized factor rating values (PFRV) of landslide triggering factors are high for slope gradient (0.2944), lithology (0.2150), drainage (0.1537), and lineament $(0.1087)$, indicating that these are the significant contributing attributes in the Shiv-khola watershed. The PFRV for other risk factors - curvature, upslope contributing area, road contributing area, and land use and land cover, are $0.0764,0.0535,0.0375$, and 0.0266 respectively, indicating that these factors are also significant landslide risk factors in the study area. The Analytical Hierarchy Process proved to be important to efficiently identify the landslide triggering factors of most importance. The frequency ratio model evaluates the significance of each class of individual factor map in connection to slope instability and their contribution to landslides. These two approaches and their integration are useful for supporting decision making for efficient management. The study shows that geological structure and lineament are important for any structural construction, especially the orientation of roads. Human construction in such areas makes the slopes more risky.

Landslide susceptibility is high in Lower Paglajhora, Tindharia, Shiviter Tea Estate, and Mahanadi Tea Estate, where damages to traffic, life, and property are common

Table 6. Accuracy assessment: comparison of landslide susceptibility with field data

\begin{tabular}{|c|c|c|c|c|c|}
\hline Class Name & Classified Total & Number Correct & Producers Correct & Users Accuracy & Accuracy Total \\
\hline Very Low & 0 & 5 & 0 & 0 & 0 \\
\hline Low & 4 & 3 & 0 & 75.00 & 0 \\
\hline Moderate & 11 & 10 & 9 & 90.91 & 90.00 \\
\hline High & 16 & 15 & 13 & 93.75 & 86.67 \\
\hline Very High & 19 & 17 & 17 & 89.47 & 100.00 \\
\hline Total & 50 & 50 & 39 & & \\
\hline
\end{tabular}


phenomena. Plying of heavy loaded vehicles should not be permitted along the Hill Cart Road, no further construction near landslide sites should be allowed, and the expansion of tea estates has to be stopped to reduce the intensity of landslide hazard risks. New laws/regulations should also restrict further construction around the zone of slope failures. Deeprooted saplings and seeds of grasses should be grown in the landslide prone areas. Land use management should be studied and improved. Development of horizontal and vertical drains to reduce upslope contributing areas and to divert drainage networks from concentrated flow in and around the highly susceptible areas could be the best management options.

\section{References}

Avinash, K. G., and K. G. Ashamanjari. 2010. A GIS and Frequency Ratio Based Landslide Susceptibility Mapping: Aghnashini River Catchment, Uttara Kannada, India. International Journal of Geomatics and Geosciences 1 (3): 343-354.

Bhattarai, P., and K. Aoyama. 2001. Mass Movement Problems along Prithwi Highway, Nepal. Annual Report of Research Institute for Hazards in Snowy Areas, Niigata University, No. 23, 85-92.

Borga, M., D. G. Fontana, D. D. Ros, and L. Marchi. 1998. Shallow Landslide Hazard Assessment Using Physically Based Model and Digital Elevation Data. Environmental Geology 35 (2-3): 81-88.

Bradinoni, F., and M. Church. 2004. Representing the Landslide Magnitude Frequency Relation. Capilano River Basin, British Columbia. Earth Surface Processes and Landforms 29 (1): 115-124.

Carson, M. A. 1975. Threshold and Characteristic Angles of Straight Slopes. In: Proceedings of the 4th Guelph Symposium on Geomorphology, 19-34. Norwich Geo Books.

Catlos, E. J., T. M. Harrison, M. J. Kohn, M. Grove, F. J. Ryerson, C. E. Manning, and B. N. Upreti. 2001. Geochronologic and Thermobarometric Constraints on the Evolution on the Main Central Thrust, Central Nepal Himalaya. Journal of Geophysical Research 106 (B8): 16177-16204.

Congalton, R. 1991. A Review of Assessing the Accuracy of Classification of Remotely Sensed Data. Remote Sensing of Environment 37 (1): $35-46$

Dai, F. C., and C. F. Lee. 2002. Landslide Characteristics and Slope Instability Modeling Using GIS, Lantau Island, Hong Kong. Geomorphology 42 (3-4): 213-228.

Dhakal, A. S., T. Amada, and M. Aniya. 2000. Landslide Hazard Mapping and Its Evaluation Using GIS: An Investigation of Sampling Schemes for a Grid-Cell Based Quantitative Method. Photogrametric Engineering and Remote Sensing 66 (8): 981-989.

Donati, L., and M. C. Turrini. 2002. An Objective and Method to Rank the Importance of the Factors Predisposing to Landslides with the GIS Methodology, Application to an Area of the Apennines (Valnerina; Perugia, Italy). Engineering Geology 63 (3-4): 277-289.

Dutta, K. K. 1966. A Landslip in Darjeeling \& Neighouring Hills Slopes in June. 1950. Bulletin of the Geological Survey of India, Series B 15 (1): 7-30.

Gallant, J. C., and J. P. Wilson. 2000. Primary Topographic Attributes. In: Terrain Analysis: Principles and Applications, edited by J. P. Wilson and J. C. Gallant, 51-86. New York: John Wiley \& Sons.

Guzzetti, F., A. Carrara, M. Cardinali, and P. Reichenbach. 1999. Landslide Hazard Evaluation: A Review of Current Techniques and Their Application in a Multi-Scale Study, Central Italy. Journal of Geomorphology 31 (1-4): 181-216.
Intarawichian, N., and S. Dasananda. 2011. Frequency Ratio Model Based Landslide Susceptibility Mapping in Lower Mae Chaem Watershed, Northern Thailand. Environmental Earth Science 64 (8): 2271-2285.

Jadda, M. 2009. Landslide Susceptibility Evaluation and Factor Analysis. European Journal of Scientific Research 33 (4): 654-668.

Jibson, W. R., L. H. Edwin, and A. M. John. 2000. A Method for Producing Digital Probabilistic Seismic Landslide Hazard Maps. Engineering Geology 58 (3-4): 271-289.

Lee, S., and U. Choi. 2003. Development of GIS Based Geological Hazard Information System and Its Application for Landslide Analysis in Korea. Geoscience Journal 7 (3): 243-252.

Lee, S., J. Choi, and K. Min. 2004. Probabilistic Landslide Hazard Mapping Using GIS and Remote Sensing Data at Boun, Korea. International Journal of Remote Sensing 25 (11): 2037-2052.

Lee, S., and B. Pradhan. 2007. Landslide Hazard Mapping at Selangor, Malaysia Using Frequency Ratio and Logistic Regression Models. Landslides Journal 4 (1): 33-41.

Lee, S., J. H. Ryu, J. S. Won, and H. J. Park. 2004. Determination and Publication of the Weights for Landslide Susceptibility Mapping Using an Artificial Neural Network. Engineering Geology 71 (3): 289-302.

Lee, S., and J. A. Talib. 2005. Probabilistic Landslide Susceptibility and Factor Effect Analysis. Environmental Geology 47 (7): 982-990.

Mallet, F. R. 1875. On the Geology and Mineral Resources of the Darjeeling District and Western Duars. Memoirs of the Geological Survey of India 2: 1-72.

Mondal, S., and R. Maiti. 2011. Landslide Susceptibility Analysis of Shiv-khola Watershed, Darjiling: A Remote Sensing \& GIS Based Analytical Hierarchy Process (AHP). Journal of Indian Society of Remote Sensing. doi:10.1007/s12524-011-0160-9.

Muthu, K., and M. Petrou. 2007. Landslide Hazard Mapping Using an Expert System and a GIS. Transactions on Geoscience and Remote Sensing 45 (2): 522-531.

Nautiiyal, S. P. 1966. On the Stability of Certain Hill Slopes in and Around Darjeeling. W.B. Bulletin of the Geological Survey of India, Series B 15 (1): 31-48.

Pandey, A., P. P. Dabral, V. M. Chowdhary, and N. K. Yadav. 2008. Landslide Hazard Zonation Using Remote Sensing and GIS: A Case Study of Dikrong River Basin, Arunachal Pradesh, India. Environmental Geology 54 (7): 1517-1529.

Pistocchi, A., L. Luzi, and P. Napolitano. 2002. The Use of Predictive Modeling Techniques for Optimal Exploitation of Spatial Databases: A Case Study in Landslide Hazard Mapping with Expert System-Like Methods. Journal of Environmental Geology 41 (7): 765-775.

Pradhan, B. 2010. Remote Sensing and GIS-Based Landslide Hazard Analysis and Cross Validation Using Multivariate Logistic Regression Model on Three Test Areas in Malaysia. Advance Space Research 45 (10): 1244-1256.

Pradhan, B., and S. Lee. 2010a. Delineation of Landslide Hazard Areas on Penang Island, Malaysia, by Using Frequency Ratio, Logistic Regression, and Artificial Neural Network Models. Environmental Earth Science 60 (5): 1037-1054.

Pradhan, B., and S. Lee. 2010b. Regional Landslide Susceptibility Analysis Using Back-Propagation Neural Network Model at Cameron Highland, Malaysia. Landslides 7 (1): 13-30.

Rowbotham, D., and D. N. Dudycha. 1998. GIS Modelling of Slope Stability in Phewa Tal Watershed, Nepal. Geomorphology 26 (1-3): 151-170.

Saaty, T. L. 1977. A Scaling Method for Priorities in Hierarchical Structures. Journal of Mathematical Psychology 15 (3): 234-281.

Saaty, T. L. 1980. The Analytical Hierarchy Process. New York: McGraw Hill.

Saaty, T. L., and L. G. Vargas. 2000. Models, Methods, Concepts and Applications of the Analytic Hierarchy Process, 1st Edition. Boston: Kluwer Academic. 
Sarkar, S., and D. P. Kanungo. 2004. An Integrated Approach for Landslide Susceptibility Mapping Using Remote Sensing and GIS. Photogrammetric Engineering and Remote Sensing 70 (5): 617-625.

Sinha-Roy, S. 1982. Himalayan Main Central Thrust and Its Implication for Himalayan Inverted Metamorphism. Tectonophysics 84 (2-4): 197-224.

Tiwari, B., and H. Marui. 2003. Estimation of Residual Shear Strength for Bentonite-Kaolin-Toyoura Sand Mixture. Journal of Japan Landslide Society 40 (2): 124-133.

Tiwari, B., and H. Marui. 2004. Objective Oriented Multi-Stage Ring Shear Test for the Shear Strength of the Landslide Soil. Journal of Geotechnical and Geoenvironmental Engineering, ASCE 130 (2): 217-222.

Vijith, H., and G. Madhu. 2008. Estimating Potential Landslide Sites of an Upland Sub-Watershed in Western Ghat's of Kerala (India) through Frequency Ratio and GIS. Environmental Geology 55 (7): $1397-$ 1405.
Windisch, E. J. 1991. The Hydraulics Problem in Slope Stability Analysis. Canadian Geotechnical Journal 28 (6): 903-909.

Wu, C. Y., and J. P. Qiao. 2009. Relationship Between Landslides and Lithology in the Three Gorges Reservoir Area Based on GIS and Information Value Model. Frontiers of Forestry in China 4 (2): 165170.

Yalcin, A. 2008. GIS Based Landslide Susceptibility Mapping Using Analytical Hierarchy Process and Bivariate Statistics in Ardesen (Turkey): Comparisons of Results and Confirmations. Catena 72 (1): $1-12$.

Yalcin, A., and F. Bulut. 2007. Landslide Susceptibility Mapping Using GIS and Digital Photogrammetric Techniques: A Case Study from Ardesen (NE Turkey). Journal of Natural Hazard 41 (1): 201-226.

Zhou, C. H., C. F. Lee, J. Li, and Z. W. Xu. 2002. On the Spatial Relationship between Landslide and Causative Factors on Lantau Island, Hong Kong. Geomorphology 43 (3-4): 197-207.

Open Access This article is distributed under the terms of the Creative Commons Attribution License which permits any use, distribution, and reproduction in any medium, provided the original author(s) and source are credited. 